\title{
Information Provision by Public Library to Agricultural Extension Agents in a Developing Country
}

Jerome Idiegbeyan-Ose, Ayotunde Owolabi, Chidi Segun-Adeniran, Ayooluwa Aregbesola, Sola Emmanuel Owolabi \& Toluwani Eyiolorunshe

To cite this article: Jerome Idiegbeyan-Ose, Ayotunde Owolabi, Chidi Segun-Adeniran, Ayooluwa Aregbesola, Sola Emmanuel Owolabi \& Toluwani Eyiolorunshe (2018): Information Provision by Public Library to Agricultural Extension Agents in a Developing Country, Public Library Quarterly, DOI: $10.1080 / 01616846.2018 .1555412$

To link to this article: https://doi.org/10.1080/01616846.2018.1555412

舟 Published online: 10 Dec 2018.

Submit your article to this journal $\sqsubset$

View Crossmark data ¿ 


\title{
Information Provision by Public Library to Agricultural Extension Agents in a Developing Country
}

\author{
Jerome Idiegbeyan-Ose ${ }^{a}$, Ayotunde Owolabi ${ }^{b}$, Chidi Segun-Adeniranc, \\ Ayooluwa Aregbesolaa, Sola Emmanuel Owolabi (1) ${ }^{a}$, \\ and Toluwani Eyiolorunshe (10)
}

${ }^{a}$ Centre for Learning Resources, Landmark University, Omu-Aran, Nigeria; ${ }^{b}$ Department of Agricultural Economics and Extension, Landmark University, Omu-Aran, Nigeria; 'Centre for Learning Resources, Covenant University, Ota, Nigeria

\begin{abstract}
One of the bedrock of Sustainable Development Goals (SDGs) is eradication of poverty and hunger. In an attempt to actualize this goal, the role of public libraries in information provision to agricultural extension agents in Nigeria becomes paramount. This paper discusses provision of information to agricultural extension agents in a developing country. It starts with the concept of extension agents and the essence of information provision to them. It further discusses types, sources and challenges of public libraries in information provision to agricultural extension workers in a developing country. Some of the challenges are as follows: poor funding of public libraries, demotivated staff, and so on. Based on these discussions, the paper recommended adequate training and retraining of staff, adequate funding of public libraries by the federal, state and local government, the revitalization of the abandoned mobile library services among others. The paper therefore concludes that information provision to agricultural extension agents by public library is very crucial for national development. The current state of poverty, hunger and lack in Nigeria and some other African countries could be reduced to a great extent if current, relevant and up-to-date information are provided by libraries to the concerned agencies.
\end{abstract}

\section{ARTICLE HISTORY}

Received 22 October 2018

Revised 30 November 2018

\section{KEYWORDS}

Information provision; public library; agricultural extension workers; agricultural extension agents; rural farmers; Sustainable Development Goals (SDGs); Nigeria

\section{Introduction}

The importance of information has earned its inclusion among the previously known factors of production, namely land, labor, capital and the entrepreneur (Okpighe 2015). It could be deduced that information is the pivot for accessing all these other factors of production.

Agricultural extension service also relies heavily on information, knowing fully well that it plays a fundamental role in the development of humanity by disseminating necessary information to famers' community on agricultural innovations, technologies, policies and several opportunities that could

CONTACT Jerome Idiegbeyan-Ose idiegbeyan-ose.jerome@Imu.edu.ng $\Theta$ Centre for Learning Resources, Landmark University, Omu-Aran, Nigeria

Published with license by Taylor \& Francis. @ Jerome Idiegbeyan-Ose, Ayotunde Owolabi, Chidi Segun-Adeniran, Ayooluwa Aregbesola, Sola Emmanuel Owolabi and Toluwani Eyiolorunshe 
improve productivity, living standards and other socio-economic aspects of the lives of farmers (Msuya et al. 2017).

The model of extension services may differ from one country to another, depending on the objectives that the countries or organizations focus on, or are willing to pursue. Australia and New Zealand conceptualize agricultural extension as agricultural advisory service while it is referred to as cooperative extension service in the USA (Ogumbameru 2001). Studies have investigated the role of agricultural extension services in agriculture: studies such as Zwane (2012); Anderson (2007); and Ngomane (2006) clearly established that increasing food production and widely spreading the innovations that encourage better approaches to farming are the main essence of agricultural extension. These functions are actually very necessary considering the report of the United Nations Food and Agricultural Organization (2015) that no fewer than 815 million people of the 7.6 billion people in the world are suffering from chronic undernourishment. The role of public libraries in providing information to agricultural extension agents cannot be overemphasized. Public libraries are custodians of information needed by these set of workers. Public libraries are libraries that are established by government at the different level to render information provision to the citizens at no cost. Similarly, Public library is generally refer to as a library that is open to the public and that serves the whole population of a local or regional community and is usually financed, in whole or in part, from public funds, its basic services are free of charge or available for a subsidized fee. (ISO 2789, 2013)

In Nigeria, for instance, the deplorable state of the public libraries calls for concern. Most of these libraries lack the basic requirements for a standard library. Also mobile library services used to be a veritable service for rural farmers and agricultural exteneion agents. Onyenachi, Akidi, and Onyekweodiri (2015) explained that Mobile library services have been used to reached segments of the rural population, it has brought improvements to rural areas, stimulated reading interest and have increased general awareness on health, nutrition, child care, family planning, farming improvement, etc. but this has gone almost extinct due to poor maintenance culture and lack of government interest. There is need for government at all levels in-charge of public library to revitalized mobile library services for improved performance of farmers and agricultural extension agents. (Idiegbeyan-Ose et al. 2015). Similarly, Motivation is an act of giving somebody a reason to act or react in a particular way. Extension agents are mostly not well paid by government because their services do not have a direct return to the government. Bitzer (2016) noted that public extension services in developing countries are identified with poor incentive and reward systems. The reason for failure in some extension services has been associated with a number of factors including poorly motivated staff. Salaries being paid to extension workers are 
generally low and there is usually lack of funds for equipment and transport, communication and information (Bello and Salau 2009; Bitzer 2016). It was also observed that Most of the farmers that extension agents deal with are usually peasant farmers who barely make their ends meet from the proceeds of the farm (Bello and Salau 2009). If extension workers are well remunerated and empowered with incentives, they will be motivated to give their best to their job; they will be willing to go any length in ensuring farmers who are in dire need of information on how to improve their farm activities are well educated.

In the same vein public library staff who are custodians of this information, need to be well remunerated to be able to discharge their duties accordingly. Lamptey, Boateng, and Antwi, (2013) observed that motivation among employees in public service institutions in Ghana has been demonstrably low. In developing countries, like Nigeria, public employees which includes public library staff are usually fond of complaining about inadequate salaries, poor working environment and lack of motivation. This has negative effect on the performance of their duties as information providers. If librarians and staff in the public libraries are well remunerated and provided with incentives they would be happy to discharge their duty.

Nigeria as a country has several public libraries. Also, there are Agricultural extension agents in various communities in Nigeria. These extension agents serve as intermediaries between the government and the rural farmers in their day-to-day activities. Their responsibility is to liaise with the rural farmers and find out their challenges and then to communicate these issues to the appropriate government agency for a solution. One of the duties of the agricultural extension agents is to provide adequate information to the farmers, and in doing that they rely on the public libraries for information provision. It is against this background that the researchers decided to discussed the information provision by public library to agricultural extension agents in a developing country

\section{Extension services and public libraries for information dissemination}

Through exploration of literature, this paper has been able to point out some of the extension services that are of utmost importance to agricultural productivity. These services however may not be possible without collaboration with public libraries in the rural communities. Extension personnel are mostly visiting agents to rural communities, whereas public libraries are situated in rural communities to ensure that the average dwellers have relevant access to information as at when due. Some of the services are as follows: 


\section{Agriculture commercialization}

Through the support provided by agricultural extension agents, farmers could be transformed from subsistent level to commercial agricultural production. This is the purpose of programs such as farmers' field school and other informal educational programs organized for farmers to see how to improve their farming system (Biratu 2008; Rohana and Bandara 2006). The public library through provision of print and non-print materials such as film shows plays an integral role in supporting educational activities that could help farmers think creatively, adopting entrepreneurial approaches to farming.

\section{Timely advice to farmers to achieve their goals}

Extension agent gives timely advice to make them aware of a problem and helps farmers to decide most important goals (Albore 2018). The librarians in the public libraries serve as the information gatekeepers to ensure that such information is repackaged, made available and accessible to users through repackaging and mobile public library services.

\section{Farmers' organization}

Agricultural extension agents have been equipped with skills to organize farmers into groups to collaborate for progress through learning, associations, and several cooperative activities. Through the group approach farmers can engage in large scale production which will automatically promote individual's socio-economic well-being (Biratu 2008). The sustenance of such learning activities and associations depend on information. Hence, professional management (storage, preservation, organization and dissemination) of the information resources provided by extension agents are catered for by the public library.

\section{Educating farmers}

Educating farmers is a major priority of extension agencies. This has been captured in the report of (FAO 2015) that when farmers are educated on government policies, use of improved varieties and machineries, there would be increase in productivity and this will automatically increase the income of every farmer. The public library could make space, audio-visual materials and personnel available to support the educational activities of extension workers to farmers. 


\section{Food security}

The capacity of extension workers to clearly communicate with farmers and convince them to adopt innovations and policies serves as major tool for food security. When farmers are carried along strategically to adopt a system of farming, they do not feel coerced, hence they put their best into it and the aftermath is high productivity. However, extension agents alone cannot successfully implement this except by partnering with the public library that ensures creation of awareness and other educational programs aimed at sustainability.

\section{Conservation of natural resource}

Based on the skills of the extension workers to influence farmers positively, natural resources could be preserved. Farmers do not enjoy being coerced but it is believed that government legislations compel farmers to yield to instructions on preservation of natural resources (Zwane 2012). Extension personnel does not use force but known strategies of persuasion to assist farmers and communities to conserve natural resources. With the help of extension personnel in collaboration with librarians in the public libraries, implicit adherence could be achieved. Selective dissemination of information, literacy programs and non-literate persons support services could help farmers maximize the benefits embedded in innovations that could help in conserving natural resources.

\section{Dissemination of useful information}

Agricultural extension agents partner with other stakeholders in agriculture to acquire necessary information in order to relate to them as information gatekeepers. Through persuasion, information repackaging and effective communication, farmers are kept abreast of development and they stay informed (Zwane 2012). Librarians in the public library as the gatekeepers of information are major in information repackaging, hence extension personnel need to constantly collaborate with them.

\section{Promoting sustainable agriculture}

According to Mengistie and Belete (2015), sustainability in agriculture could be sustained through extension services as farmers are constantly being educated and assisted through grassroot information dissemination and educational programs. The public library is said to be the 'last hope' of the common man when it comes to information seeking. Grassroot approach to information dissemination could best be done by librarians who can use 
diagrams, local dialects of the rural people to disseminate information for promotion of sustainable agriculture.

\section{Types of information resources used by agricultural extension personnel}

The need for agricultural extension agents to rely heavily on information becomes sacrosanct considering the enormous task of ensuring food sufficiency among the 7.6 billion persons in the world. IFPRI (2009) reported that $83 \%$ of the world population directly relies on agriculture for livelihood and the remaining $17 \%$ also depends on agriculture-related cottage industries such as textiles, leather, and food oil processing. Wulandari (2015) in relation to types of information needed by agricultural extension agents classified them into three categories namely: extension service information, innovation information, and extension role information.

\section{Extension service information}

This connotes information on the implementation of agricultural extension service. These information include: how to prepare materials to facilitate extension services; how to coordinate farmers; provision of current price tags on commodities in the market; sourcing for agricultural infrastructure; marketing procedure; development of high quality agricultural products; coordination of post-harvest activities; and evaluation of completed extension activities.

\section{Innovation information}

These are information about new inventions, modernization and improvements in agriculture. It includes information on the advantages and disadvantages of such innovations from technical, economic and social aspects, as well as farmer's responses to these innovation.

\section{Extension role information}

This is information about new agricultural policy, farmer's empowerment and management of agricultural institutions as well as establishing good relationships between agricultural extension workers and the community.

\section{Sources of information used by agricultural extension personnel}

Wulandari (2015) categorized sources of information used by agricultural extension personnel into five parts which are as follows: 


\section{Interpersonal sources}

These include discussion with colleagues, farmers, senior officers, agricultural researchers and correspondences with researchers.

\section{Print media}

These are newspapers, magazines, brochure, leaflets, textbooks and journals based on agriculture.

\section{Personal experience}

These are extension personnel's observations from their research and tests, and general personal experiences in relation to agriculture.

\section{Scientific meeting}

This includes training, field research projects, workshops, conferences attended by extension personnel.

\section{Electronic media}

They comprise information derived from electronic media such as television, radio, video, and the internet.

\section{Challenges of information provision by public libraries to agricultural extension agents in Nigeria}

Some challenges encountered by public libraries in the course of providing information to the agricultural extension workers are highlighted below:

\section{Information repackaging}

This is simply the process of changing the original format of an information resource to suit the information need of a particular user or a group of users. Ilo et al. (2018), Idiegbeyan-Ose, Ilo, and Isiakpona (2015). This captures the activities of librarians in the public library as they engage in ensuring that farmers get information in the format that conforms to their knowledge level and backgrounds. In some cases where quality information resources are maximally available in the libraries to be accessed by extension agents, they are usually not fully utilized by these farmers if they are not properly repackaged to suit their peculiar information needs. The agricultural extension workers or agents may face difficulty in the process of accessing these information if 
the information materials have not been properly repackaged to suit the literacy level of the farmers who are mostly illiterates or semi-literates. Hence this poses a major challenge to the agricultural extension workers.

\section{Attitude of farmers and extension agents}

The farmers in this situation are the major clients of the agricultural extension agents, for this reason, Idiegbeyan-Ose et al. (2015) averred that extension agents have the obligation to get necessary information from the library and other information centers and make them available in the format suitable for the understanding of these illiterate and semiliterate farmers. The farmers in turn make use of the knowledge drawn from these resources to improve their agricultural activities. However some of these farmers have been observed to display very unwelcoming and poor attitudes toward these extension agents. These farmers usually find it difficult to adapt to innovations and changes being presented to them by the extension agents as they are adamant on the traditional methods of farming. They sometime display an attitude of distrust toward these agents. This negative and nonchalant attitudes dispirit the extension agents and in turn affects the whole process of providing information to these farmers. This poses a challenge to library personnel as well, because the purpose of making these materials available to the agents is defeated. Until information is utilized, the purpose of establishing the library is not achieved. The other extreme of this challenge is the poor attitude of the extension workers themselves toward the acquisition of this information and ensuring it gets to the farmers who need it at the appropriate time. This attitude by these agents has been observed to be associated with low level of motivation and remuneration. Belay (2003) averred that motivation and good remuneration are known to be pertinent elements in ensuring job satisfaction and this is considered as a proactive human resource strategy.

\section{Lack of infrastructures}

Public library needs basic infrastructures to function and operate effectively and efficiently. Some of these infrastructures include electricity, internet facilities, information and communication technology tools, audio-visual materials, etc. However, these basic infrastructural are lacking in most of the public libraries in Nigeria, this hinder the effective information provision to these set of workers.

\section{Low level of competency}

Another major challenge faced by public library personnel during the process of information provision to agricultural extension workers is the low level of 
competence on the part of extension workers. Their level of competency in terms ICT skills, could affect the process of information dissemination. Hence, Teshome, Sigute and Shayom (2015) reiterated that the capacity of the extension workers affects the transfer of information and technology to farmers in the rural areas.

\section{Farmers' educational background}

Farmers are the major users of the information provided by the extension workers and their level of education may mar the process of disseminating information to them. Some of these farmers do not understand English language hence, extension workers need to switch to indigenous languages. Sometimes it becomes a herculean task to make information accessible to these farmers as interpretation becomes difficult if the extension worker or librarian does not understand the local language of the farmers (Idiegbeyanose and Akpoghome 2009; Idiegbeyan-ose, Olalekan, Ilo and Odion 2015)

\section{Conclusion}

Information provision to agricultural extension agents is very crucial for national development. The current state of poverty, hunger and lack in Nigeria and other African countries could be reduced if current, relevant and up-to-date information are provided by public libraries. This may lead to improvement in term of crops production, storage and preservation strategies, and market analysis information. At the long run, the level of hunger and poverty in Nigeria will be alleviated, the Gross Domestic Product (GDP) will increase and the purpose of the Sustainable Development Goals (SGDs) will be actualized.

The role of public library in enabling extension service personnel to achieve their set objectives is paramount. Services rendered by public libraries such as information repackaging, translation, presentation of documentaries through videos and literacy programs among others are the pivots that extension programs could rest upon to ensure deployment of innovations that could boost productivity of rural farmers who need information which is now a very important factor of production. It has been established that librarians are information gatekeepers and the public library is the last hope of the common man with respect to information seeking; hence the need for extension service providers to consistently collaborate with them. 


\section{Recommendations}

\section{Remoteness of farmers}

In Nigeria, majority of farmers reside in rural communities that are referred to as villages due to their remoteness from the urban areas that have the basic amenities that aid productivity and promote general comfort. Most of these villages do not have good roads that should encourage quick transportation of farm produce before decadence sets in; water, electricity, standard schools are also not available. These are some of the fulcrums for low productivity and subsistent farming in these communities. Aina (2004) vividly depicted the characteristics of farmers in Nigeria, stating that they are subsistent farmers, lacking required educational exposure and are predominantly illiterates who however require timely information for survival. Suggestion was made by Aina (2004) that the curriculum of library schools in Nigeria require review in order to include skills to specifically render services to rural dwellers just as agricultural extension agents are trained (Iwe 2003). This sis due to the fact that one major challenge to deploying agricultural research and innovation among farmers is low level of education and outright illiteracy (Chisita 2011). Farmers therefore need personnel that are trained in the art of information repackaging to suit their level of understanding. This realization is a sound basis for collaboration between public library personnel and agricultural extension agents.

\section{Adequate funding of public libraries}

Government at all levels, that is federal, state and local should take the issue of public library funding to be utmost priority, this will empower the public library for effective information provision to agricultural extension agents in Nigeria

\section{Training and retraining of workers}

One major way to enhance access to available information by agricultural extension workers is by organizing regular training and retraining for extension agents. These training will sharpen their skills and increase their level of competence when using the library (Lamptey, Sambo, and Hassan 2016). Public library staff should also be included in the training and re-training for enhance skills development.

\section{Staff motivation}

The remuneration and motivation of public library staff and agricultural extension workers is an essential ingredient for better service delivery. The 
better their remuneration, the better the level of their effectiveness and zeal to carry out information services to these set of workers

\section{Provision of needed infrastructure}

It is also paramount that government and other concerned agencies provide the needed infrastructure for the public library. Internet and other ICT tools should be make available in public libraries in Nigeria for effective information provision to agricultural extension agents.

\section{Revitalization of mobile public library services}

Public libraries in Nigeria should re-introduced the abandoned mobile library services to rural communities in Nigeria. This will go a long way in assisting the agricultural extension agents in rural dwellers to relevant, current and up-to-date information for better services to the rural farmers.

\section{Provision of relevant human resources in public libraries}

Public libraries should be provided with the right mixed of human resources to enhance the process of information delivery to agricultural extension agents in Nigeria.

\section{ORCID}

Sola Emmanuel Owolabi (D) http://orcid.org/0000-0002-1250-2361

Toluwani Eyiolorunshe (10) http://orcid.org/0000-0001-9028-7161

\section{References}

Aina, L. O. 2004. Library and information services to the neglected majority in Africa: The need for a restructuring of LIS curriculum in Africa. In: Towards a Knowledge Society for African Development. Proceedings of the 16th Standing Conference of Eastern, Central and Southern African Librarians, 292-303. Kampala: Uganda Library Association.

Albore, A. 2018. Review on role and challenges of agricultural extension service on farm productivity in Ethiopia. International Journal of Agricultural Education and Extension 4 (1):093-100.

Anderson, J. R. 2007. Agricultural advisory services: Background paper for the World Development Report 2008. Washington, D.C. World Bank, Botha

Belay, K. 2003. Agricultural extension in Ethopia: The case of participatory demonstration and training extension system. Journal of Social and Development Affairs 18 (1):49-84.

Bello, M., and E. S. Salau. 2009. A case for participatory (cost sharing) approach to agricultural extension delivery in Nigeria. Journal of Agricultural Extension 13 (1):84-94.

Biratu, G. 2008. Agricultural extension and its impact on food crop diversity and the livelihood of farmers in Guduru, Eastern Wollega, Ethiopia. A thesis submitted in partial 
fulfillment of the requirement for the degree of Master of Science in Management of Natural Resources and Sustainable Agriculture (MNRSA), Norwegian University of Life Sciences (UMB)

Bitzer, V. 2016Incentives for enhanced performance of agricultural extension system. (Kit Working Paper. 2016:6). www.kit.nl/sed/publications.

Chisita, C. T. 2011. Role of libraries in promoting the dissemination and documentation of indigenous agricultural information: Case study of Zimbabwe Meeting. 78 Information systems for indigenous knowledge in agriculture. Agricultural Libraries. Cape Town

Food and Agriculture Organization, International Fund for Agricultural Development, World Food Program. 2015. The state of food insecurity in the World 2015. Strengthening the enabling environment for food security and nutrition. Rome: FAO.

Idiegbeyan-Ose, J.Akpogho. 2009. Information as an effective tool for rural development. International Journal of Library and Information Science 1 (3):022-028. http://www.acade micjournals.org/ijlis.

Idiegbeyan-Ose, J., P. Ilo, and C. Isiakpona. 2015. The 21st century library and information services for the enhancement of teacher education. In Handbook of research on enhancing teacher education with advanced instructional technologies, ed. Ololube, N.P., Kpolovie, J.P. and Makewa, L.N. USA: IGI-,Global. https://www.igi-global.com/chapter/the-21st-centurylibrary-and-information-services-for-the-enhancement-of-teacher-education/133804.

Idiegbeyan-Ose, J., A. Olalekan, P. Ilo, and F. Odion. 2015. Availability of library and information services for rural community development in Nigeria: A case study of Ewatto, in Esan South East LGA of Edo State. Evidence Based Library and Information Practice 201510 (4). https://journals.library.ualberta.ca/eblip/index.php/EBLIP/article/ view/24026/19300.

IFPRI. 2009. Review and recommendations for strengthening the agricultural extension system in Ethiopia. Addis Ababa: IFPRI.

Ilo, P., L. Ekwueme, C. Segun-Adeniran, and H. Michael-Onuoha. 2018. Accessibility of reproductive health information by rural women: The library as a tool. Conference Paper delivered at the 1st International Women's Multidisciplinary Conference. Ota: Covenant University.

ISO (International Organization for Standardization). 2013. International library statistics. Information and Documentation. Accessed November 25, 2018. https://www.iso.org/obp/ ui/\#iso:std:iso:2789:ed-5:v1:en.

Iwe, J. I. 2003. Library and information in sustainable rural development in Nigeria. Information Development: SAGE Publications 19 (3):169-77. doi:10.1177/ 0266666903193004.

Lamptey, R. B., M. S. Baoteng, and I. K. Antwi 2013. Motivation and performance of librarians in public universities in Ghana. Library Philosophy and Practice. Accessed November 25, 2018. http://digitalcommons.unl.edu/libphilprac/911.

Lamptey, R. B., I. A. Sambo, and A. A. Hassan. 2016. Disseminating and promoting agricultural information through library and information services in Ghana. Qualitative and Quantitative Methods in Libraries 5:901-07.

Mengistie, M., and M. Belete. 2015. A review on the role of extension service for agricultural transformation with particular emphasis on Ethiopia. Journal of Agricultural Economics, Extension and Rural Development 2 (1):224-28.

Msuya, C. P., F. K. Annor-Frempong, M. N. Magheni, R. Agunga, C. O. Igodan, A. A. Ladele, K. Huhela, N. M. Tselaesele, H. Msatilomo, C. Chowa, et al. 2017. The role of agricultural extension in Africa's development, the importance of extension workers and the need for change. International Journal of Agricultural Extension 5 (1):59-70. 
Ngomane, T. 2006. Research and extension processes and practices in relation to smallholder agriculture in Africa: Present, past to present. South African Journal of Agricultural Extension 35 (2):199-220.

Ogumbameru, B. O. 2001. Practical agricultural communication. Ibadan, Nigeria: Daily Graphics Ltd.

Okpighe, S. O. 2015. The seven factors of production. British Journal of Applied Science \& Technology 5 (3):217-32. www.sciencedomain.org.

Onyenachi, J. C., J. O. Akidi, and N. E. Onyekweodiri. 2015. Library services for rural transformation. International Journal of Library \& Information Science 4 (2):40-46.

Rohana, P. M., and R. M. A. S. Bandara. 2006. Commercialization of agriculture and role of agricultural extension. Sabaragamuwa University Journal.

Teshome, Z., A. Shigute, and A. Seyoum. 2015. The challenges of development agents in technology dissemination for extension purposes in southern region, Ethiopia. Advances in Agricultural Sciences 1 (1):1-9.

Wulandari, R. (2015). Information Needs and Source Information of Agricultural Extension Workers in DIY. Available at https://media.neliti.com/media/publications/225813-informa tion-needs-and-source-information-ad8075c1.pdf

Zwane, E. M. 2012. Does extension have a role to play in rural development? South African Journal of Agricultural Extension 40 (1):6-2. 